International Journal of Agriculture, Environment and Bioresearch

Vol. 4, No. 03; 2019

ISSN: $2456-8643$

\title{
EFFECTIVENESS OF INDIGENOUS METHOD OF FOOD CROP STORAGE AND PRESERVATION IN ETCHE ETHNIC NATIONALITY.
}

\author{
Nnodim, A. U. \\ Department of Vocational and Technology Education ,Rivers State University, Nkpolu, Oroworukwo, Port-Harcourt \\ Emiri, U. N. \\ Department of Agricultural Education ,Isaac Jasper Boro College of Education Sagbama, Bayelsa State
}

http://doi.org/10.35410/IJAEB.2019.157171

\begin{abstract}
The study was carried out to determine the effectiveness of indigenous methods of food crops storage and preservation among farmers in Etche ethnic nation. The study design was descriptive survey. The target population was 450 members of registered crop farmers organization in the two local Government Areas in the study area. The sample size was 120 randomly selected from the organizations. The instrument for data collection were structured questionnaire and interview schedule for those who found it difficult to respond to the questionnaire. The collected data were analysed descriptively using Mean and Standard Deviation. The findings identified some methods, such as storing in the barn, on the platform, processing to another form among others, as being effective for storing and preserving tuber crops. For cereals and legumes majority of the methods were effective but for fruits and vegetables the methods were less effective. Therefore, it was recommended that framers should be encourage to adopt modern methods of crop storage and preservation.
\end{abstract}

Keywords: Storage, preservation, tubers, legumes, cereal

\section{INTRODUCTION}

People are accustomed to traditional food crops, how to cultivate process, and enjoy dishes made from them as well as preserving or storing them for future use. For example, to see them through the hungry season, rural people grow traditional food plants near their homes, without expensive inputs, and have good storage qualities (Katz and Weaver 2003). Indigenous people have therefore developed methods of storing these crops since time immemorial. Proper crop storage plays an integral part in ensuring domestic food supply and ensure seed quality and vigour is maintained (Thamaga et al, 2004).

It has been documented that Sub-Saharan Africa is home to 30 million under nourished children i.e. about one in every five persons (Black et al, 2008). High post harvest food losses, arising largely from limited food preservation capacity, is a major factor constraining food and nutrition security in the developing countries of West Africa, where seasonal food shortages and 
nutritional deficiency diseases are still a major concern. Greater portions of this amount is lost due to various factors such as poor infrastructure, low levels of technology and low investment in the food production systems, pest, inadequate policies, poor storage, climate and other factors. (Gutavsson et al, 2001). It has been estimated that in Sub-Saharan Africa more than $40 \%$ of food losses occur at post harvest and processing levels, while in the industrialized countries more than $40 \%$ of the food losses occur at retail and consumer levels (FAO, 2011). One way to arrest this huge post harvest losses and improve food security is the recognition, promotion and utilization of African indigenous knowledge, skills and practices in food processing, preservation, and storage. This is important because, indigenous knowledge (IK) has been used at the local level by communities as the basis for decisions making pertaining to food security, human and animal health, education, natural resources management, and other vital activities (Gorjestani, 2004). Indigenous knowledge refers to what indigenous people know and do, and what they have known and done for generations, practices that evolved through trial and error and proved flexible enough to drop with change. (Melchias, 2001).

Indigenous people have developed indigenous practices and technology for the storage, processing and preservation of food. By storing and preserving food, households ensure that they secure food without jeopardizing future food consumption, (Kamwendo and Kamwendo 2014).

In most parts of Nigeria the bulk of the agricultural produce aside the ones consumed immediately after harvest is preserved and processed using simple indigenous knowledge and practices. Women use these techniques predominantly and they provide income and employment. For example, cereals and legumes play an important role in the diet of the majority of the population, and therefore need to preserved for better income. Legumes are used in various forms in Nigeria, such as boiled beans, cakes (akara), been stews, moi-moi, roasted or boiled groundnuts, ground-nut paste, groundnut soup, and groundnut cakes. Certainly indigenous knowledge and practices cannot be overlooked.

The production of garri from fresh cassava tubers is one of the major way of cassava utilization in Nigeria. This is because Nigeria is one of the leading producers of cassava in the world with an annual production of 57 million metric tons (FAO, 2015). Garri is a popular product and its production is the most improved technology in cassava processing. Garri with a moisture content of 6 to $10 \%$ has a long shelf-life when appropriately packaged. It's wide consumption is attributed to its relatively long shelf life compared to other food products from cassava, as well as its ease of preparation for eating. (Sanni et al, 2008).

Storage facilities not only offer the opportunity to provide a supply of food between staple crop harvests but farmers are able to improve farm incomes by storing crops and selling at premium prices when demand outstrips supply later in the post-harvest period. (Olakojo and Akinlosotu, 2004). Dried foods like corn, pepper and vegetables are stored over the fireplace to prevent spoilage. They are also stored in bags with the combination of local pesticides like pepper, tobacco, neem leaves, wood ash etc. Weevils could be prevented from burrowing all kinds of grain by putting dry gum tree leaves between layers of grain in the sacks or granary (Chirimuuta and Mapolisa, 2011). Other storage structures include a traditional silo that is made of mud and 
twigs. This structure is relatively inexpensive but it is not airtight and often exposes the stored maize to harsh environmental conditions such as sun and rain.

In Malawi, a raised wooden structure known as the Msanja constructed above the fire place is used as a storage place for grains such as millet, sorghum, maize and all sorts of peas. The reason for storing harvested crops in this structure was to protect them from weevils and other pests. The soot coating made grains bitter and not edible by both pests and rodents. This was not only a cost-free technology but an effective way of ensuring food security (Kamwendo and Kamwendo, 2014). Some of these structures were sometimes weak and so could allow insects to enter and provide an environment for storage fungi to thrive (Modi, 2004). In Zimbabwe, local granaries known as maturaitsapi in Shona or Izipala in Ndebele which were cleaned, smeared with cowdung before being filled with grain and then latter completely sealed. The sealing itself was very critical and it was informed by a lot of local wisdom on the life cycles of pests and pest control systems. Sealing the granary ensured that no living organism accessed oxygen for respiratory and reproductive purposes (Chirimuuta and Mapolisa, 2011). In most situations, maize is traditionally left to dry in the fields prior to harvesting (Olakojo and Akinlosotu, 2004).

In Nigeria, yams tubers are stored in barns, which are usually built on an open ground but is usually shaded to protect the yams from the scorching effect of the sun. Barns basically consist of walls of vertical poles cut from the bush or planks bought from the market, if left unbarked, will take root when set on the ground (Ezeike, 1995).

Other indigenous methods of food storage include storing in baskets, storing cocoyam and potatoes in the soil to prevent spoilage. Various traditional methods of sweet potato storage such as heap storage, in-ground storage, platform and pit storage methods have been practiced in Nigeria and across African countries by farmers but the most common traditional method is the pit storage. Pit storage of sweet potatoes has been reported in Indonesia, Zimbabwe, and Malawi (Woolfe, 1992) and in Nigeria (Awojobi, 2004). Pit storage can generally be considered to be cheap for the rural communities since it requires minimum materials. According to Yakubu (1999), the pit storage method appeared to be the best traditional method because deteriorations such as sprouting moisture loss and pathological losses were minimal compared to other storage methods.

Vegetables are dipped into tap or well water to restore turgidity to the tissue that appear wilted. They may be wrapped with a polythene material or other plant leaves like cocoyams, plantain or bananas. These materials probably conserve moisture. They are brought out in the nights and left outside in an open space where dews could fall on them and sent in the day. Keeping agricultural produce for sometime after harvesting with little or no deterioration has been a very major problem confronting crop production in developing countries especially Nigeria. High post harvest food losses has been recorded on account of poor and limited food crop storage/preservation capacity. Against this back drop rural farmers are compelled to sell off their produce at a give away price to guide against spoilage and waste. The indigenous method of crop preservation among rural farmers in Etche has been practiced over the years, yet they harvest their crops in piece meal and sell it off immediately after harvest with little for storage for the 
next cropping season. This is an indication that such methods are not helping much and could jeopardize the chances of increased income from farm produce. Therefore, there is the need to investigate the various methods of crop storage and preservation, and their effectiveness hence this study.

\section{Objectives of the Study}

1. Identify various indigenous methods of food crop storage and preservation in Etche ethnic nation.

2. Determine the extent of effectiveness of the identified indigenous method of food crop storage/preservation in the study area.

3. Determine the strategies for enhancing food crop preervation in the study area.

\section{Research Questions}

1. What are the various indigenous methods of storing food crops in Etche ethnic Nationality?

2. What is the extent of effectiveness of indigenous method of food crop storage/ preservation?

3. What are the strategies for enhancing food crop storage/preservation in Etche Ethnic nationality and how can the method of preservation be improved?

\section{Significance of the Study}

Nigeria is faced with dire need for food security. There is therefore an urgent need to look for more practical ways to tackle this challenge. One of such ways is the promotion of food crop storage and preservation. Since the target of the Federal Government of Nigeria is to increase food productivity, this can be attained by food crop preservation after harvest, thereby serving as a survival strategy. This study will reveal whether the traditional long-term methods of food crop preservation such as drying, used for fruits and vegetables, processing into flour used for tubers and grains have been effective or not. This will help to proffer solutions to food crop preservation which will consequently enhance reduction of food insecurity.

\section{METHODOLOGY}

The study was conducted in Etche ethnic nation comprising of Etche and Omuma Local Government Areas of Rivers State, Nigeria. The choice of the area was based on the active participation of the people in agriculture, particularly crop production. Farming is the major occupation in the area and the production is mostly at subsistence level. The prominent crops in the Local Government Areas include maize, cassava, yam, plantain and vegetables. Descriptive survey design was adopted for this study. The population of the study was 450 members of 15 registered crop farmer organization in the Local Government Area of Etche and Omuma. Sample size was 120, randomly selected (8each) from the farmers organizations. The instruments for data collection were structured questionnaire and schedule interview duely validated and 
International Journal of Agriculture, Environment and Bioresearch

Vol. 4, No. 03; 2019

ISSN: $2456-8643$

reliability coefficient (r) of 0.75 established using test-retest method. Data collected were analysed descriptively using Mean and standard deviation. 


\section{RESULTS AND DISCUSSION}

\section{Research Question 1:}

What are the various indigenous methods of storing food crops in Etche ethnic Nationality?

The following are the various indigenous methods of food crop storage/preservation

Table 1: Indigenous Methods of Storing food Crops

\begin{tabular}{|lllll|}
\hline N/S & Tubers & $\bar{X}$ & SD & Remark \\
\hline 1. & Stored in barns & 3.60 & 0.80 & Agreed \\
2. & Arranged on a platform under shades & 3.20 & 0.83 & Agreed \\
3. & Stored in the rooms & 2.45 & 0.97 & Disagreed \\
4. & Stored in baskets and sacks & 2.25 & 0.88 & Disagreed \\
5. & Stored in a processed form as flour & 2.40 & 0.81 & Agreed \\
6. & Stored as dried chips & 2.20 & 1.09 & Agreed \\
7. & Stored by burying in the soil (Pit storage) & 3.10 & 0.82 & Agreed \\
8. & Processed into garri, foofoo or flour especially cassava & 3.15 & 0.52 & Agreed \\
9. & Stored as tapioca (dried chips) especially cassava & 3.85 & 0.66 & Disagreed \\
10. & Tubers are coated with paste made from earth or mud & 2.05 & 1.12 & Disagreed \\
11. & Placed between layers of palm leaves in a trench & 2.25 & 0.90 & Disagreed \\
& covered with soil and a shade made over the trench & & & \\
12. & Cspecially cassava & & & \\
13. & Sorms are coated with paste made from mud & 2.60 & 0.97 & Disagreed \\
14. & Corms are coated with paste made from wood ash & 3.05 & 0.85 & Agreed \\
& $\quad$ B Cereals and Legumes & & & \\
15. & Stored when dried without the husk, especially maize & 3.60 & 0.97 & Agreed \\
16. & Grains are stored in air-tight containers such as & 2.40 & 1.07 & Disagreed \\
& calabashes and Earthen pots & & & \\
\hline & & & & \\
\hline
\end{tabular}




\begin{tabular}{|lllll|}
\hline 17. & $\begin{array}{l}\text { Dried cobs with husk are hung over fire place } \\
\text { especially maize }\end{array}$ & 0.30 & Agreed \\
18. & $\begin{array}{l}\text { Pulse stored in bundles, especially cowpea and kept on } \\
\text { platform away from moisture }\end{array}$ & 0.90 & Agreed \\
19. & Stored in a processed form as flour & 2.00 & 1.00 & Disagreed \\
20. & Stored in bags & 2.80 & 0.87 & Agreed \\
21. & Stored in air-tight containers with dried pepper applied & 3.50 & 0.35 & Agreed \\
\hline
\end{tabular}

\section{Fruits and Vegetable}

\begin{tabular}{|c|c|c|c|c|}
\hline 22. & Sun-drying before storing especial pepper & 2.95 & 0.89 & Agreed \\
\hline 23. & Stored as pod under shade especially fluted pumpkin & 3.00 & 0.84 & Agreed \\
\hline 24. & $\begin{array}{l}\text { Stored as dried seeds in air tight container especially } \\
\text { cucumber seeds }\end{array}$ & 3.25 & 0.81 & Agreed \\
\hline 25. & Stored in baskets especially cucumber pods & 2.45 & 1.08 & Disagreed \\
\hline 26. & $\begin{array}{l}\text { Stored in container when dried and crushed especially } \\
\text { bitter leaf }\end{array}$ & 2.90 & 0.94 & Agreed \\
\hline 27. & $\begin{array}{l}\text { Leaves tied with fresh plantain/cocoyam leaves and kept } \\
\text { away from the sun. }\end{array}$ & 2.05 & 0.86 & Disagreed \\
\hline 28. & $\begin{array}{l}\text { Stored as dried seeds on a platform, especially fluted } \\
\text { pumpkin }\end{array}$ & 3.00 & 0.97 & Agreed \\
\hline 29. & Leaves are kept in the dews at night & 2.20 & 0.98 & Disagreed \\
\hline 30. & $\begin{array}{l}\text { Stored as dried seeds in air-tight container especially Okro } \\
\text { and tomatoes }\end{array}$ & 3.25 & 0.76 & Agreed \\
\hline 31. & $\begin{array}{l}\text { Bundle of dried fruits are hung over fire place, especially } \\
\text { Okro }\end{array}$ & 3.80 & 0.34 & Agreed \\
\hline
\end{tabular}

Source: field survey: 2019

\section{Research Question 2:}

What is the extent of effectiveness of indigenous method of food crop preservation. 
The following are the extent of effectiveness of indigenous method of food crop preservation.

Table 2: Extent of Effectiveness of Indigenous Method Preservation

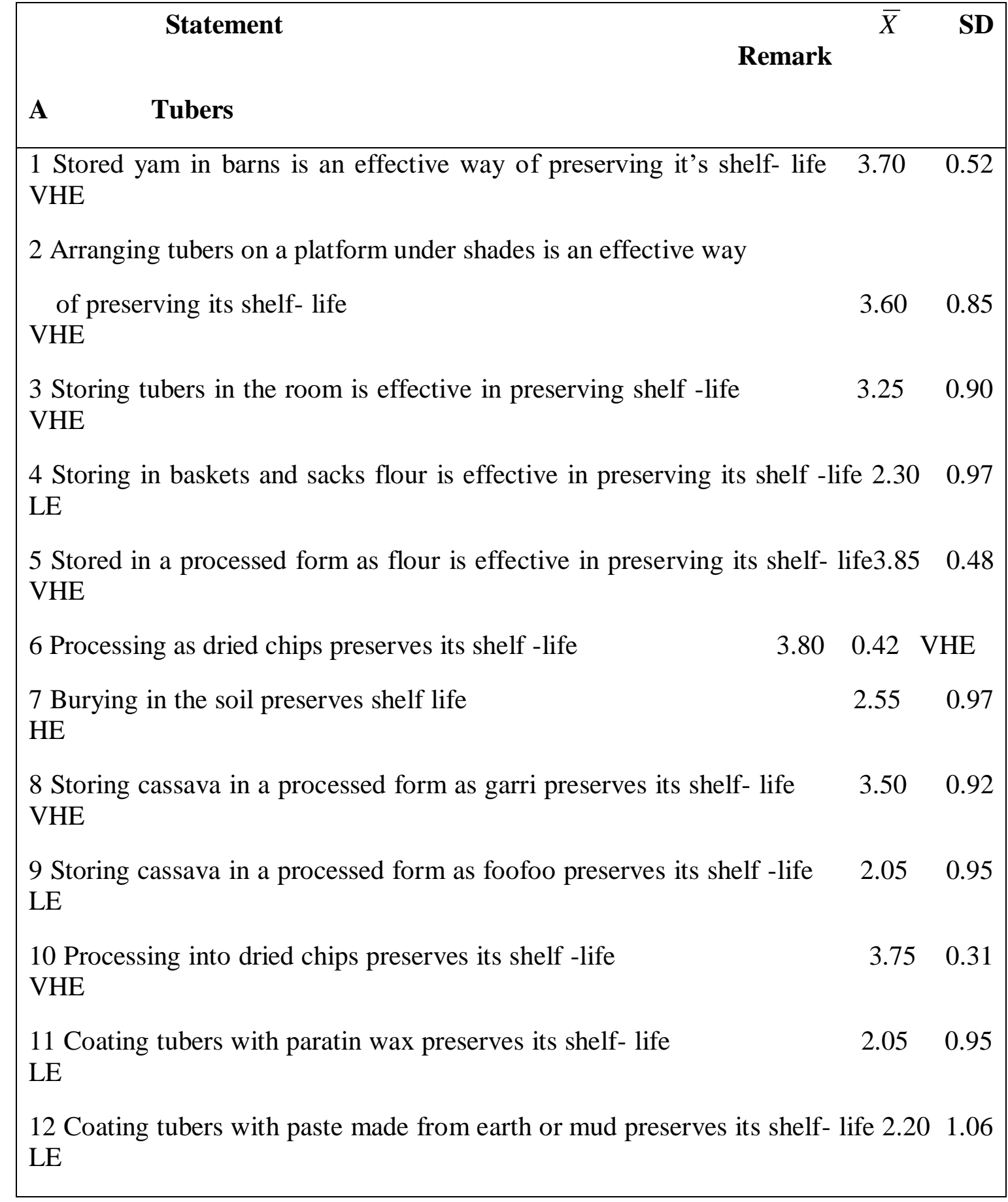


13 Placing tubers between layers of palm leaves in a trench covered with soil

Preserves its shelf-life

$2.25 \quad 1.11$

LE

B Cereals and Legumes

14 Storing dehusked maize cob preserves its shelf-life VHE

15 Storing gains in air-tight containers such as calabash and earthen

pots preserves its shelf-life

HE

16 Hanging dried maize cob with husk over fire place preserves its shelf-life $3.75 \quad 0.53$ VHE

17 Pulses stored on a platform away from moisture preserves its shelf-life $3.00 \quad 0.95$ HE

18 Storing gains in a processed form as flour preserves its shelf-life VHE

19 Storing gains in bags preserves its shelf-life

LE

20 Storing grain in containers with dried pepper preserves its shelf-life HE

\section{A Fruits and Vegetable}

21 Sundrying pepper before storage preserves its shelf-life

$\mathrm{HE}$

22 Storing the pod of fluted pumpkin preserves its shelf-life LE

23 Storing dried cucumber seeds in air-tight container preserves its shelf-life $2.40 \quad 0.86$ LE

24 Storing cucumber pods in wooden baskets preserves its shelf-life LE

25 Storing dried crushed bitter leaf in a container preserves its shelf-life $\mathrm{HE}$

26 Tying leaves with fresh plantain or banana leaves preserves its shelf-life $1.90 \quad 1.03$ 

VLE
27 Storing dried seeds of fluted pumpkin on a platform preserves its shelf-life 2.250 .89 LE
28 Keeping leaves in the dews at night preserves its shelf-life VLE
29 Storing dried Okro seeds in air-tight container preserves its shelf-life VHE
30 Hanging dried Okro fruits over fire place preserves its shelf-life $0.46 \mathrm{VHE}$

Source: field survey

\section{Research Question 3}

What other ways can the method of food crop preservation be improved?

The following are other ways of improving the method of preservation of food crops.

Table 3: Improved Method of Storage/Preservation Food Crops

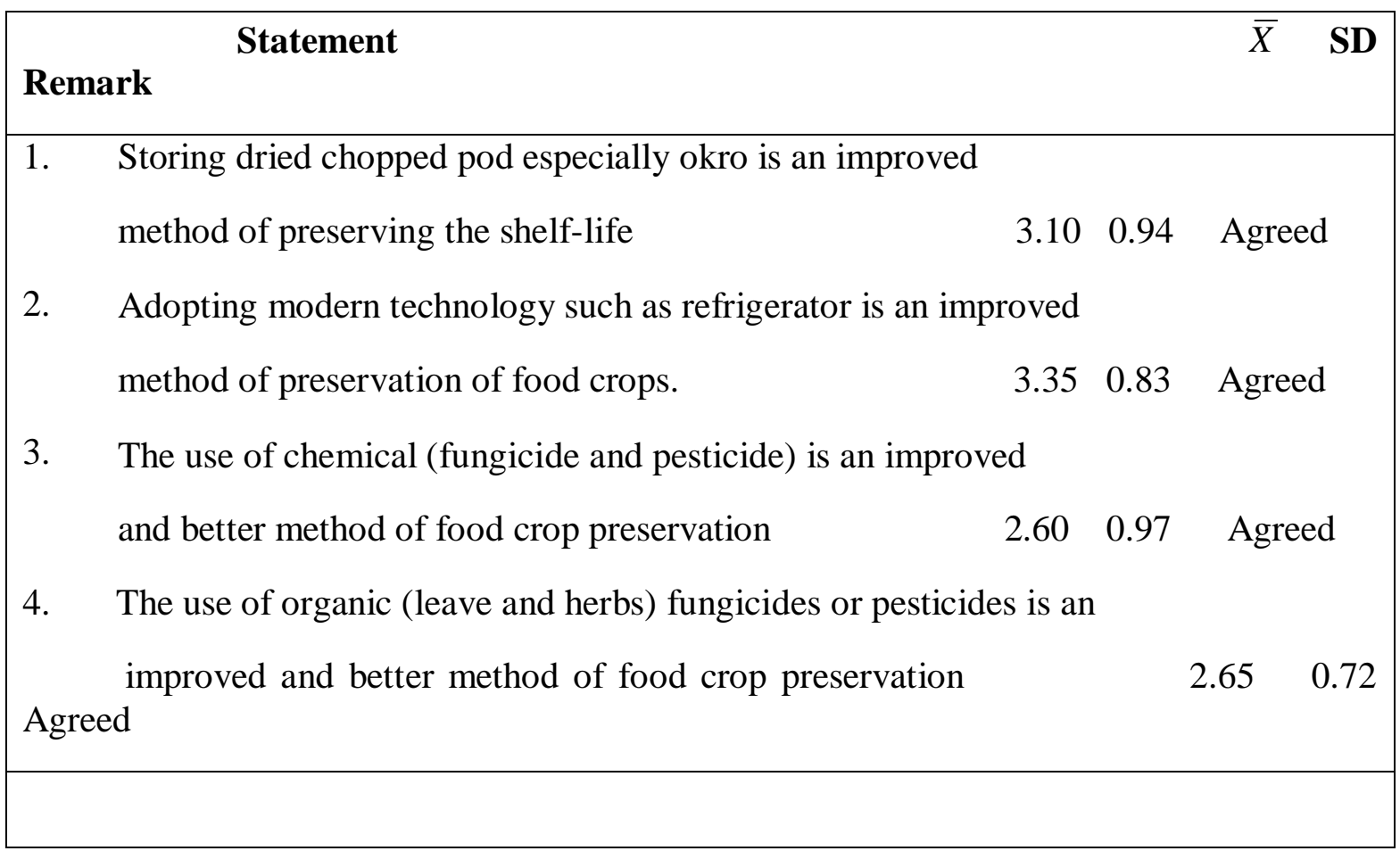

Indigenous Methods of Storing food Crops 
Table I showed the indigenous methods of food crop storage.

Results in Table I showed that storing yam tubers in barns, arranging on a platform under shades and burying in the soil are the most adopted and preferred method of storage, this agrees with the findings of Yakubu (2000), who obverse potatoe store in the soil was better preserved. While processing yam tubers into flour or chips is not indigenous method of storage among the locals, cassava is better store when it is processed into garri, tapioca and foo-foo. The method of processing of cassava which is supposedly a staple food crop of Etche people determines duration of storage. However processing cassava into cassava flour or coating cassava tuber with paste made from mud is alien to the locals. Storing the tubers in sacks or trench, covered with soil is not common storage method as reported by the respondents. Storing cocoyam in the soil, in the room on a platform under shade and applying wood ash on corn are more acceptable method of storage as seen in Table 1 .

\section{Cereals and Legume}

Dried maize cobs with husk hung over fire place recorded a high mean value of (3.90) comparable to dehusked dried maize with the mean value of (3.60) and maize grain stored in airtight container with dried pepper applied with mean value (3.50). These values were not unexpected because the smoke from the fire which surrounds the cob tries to keep away weevils and other pests. This confirms earlier findings of Chirmuuta and Mapolisa (2011). The pungent odour of dried pepper which surrounds the grains in a container also keep away weevils and other pests and the air- tight containers ensure that moisture is kept away to guide against deterioration. Storing grains in a processed form as flour also ensures that it does not deteriorate. However, this method of storage is not common among the rural farmers in Etche.

\section{Fruits and Vegetable}

Storage of leafy vegetable is almost impossible because of its high content which predispose it to quick deterioration, because they are unable to stay long after harvest. Hence, they are termed perishable. The common method of storage in Etche is either keep the leaves in dews at night or tie in a fresh plantain leaves which recorded low mean value (2.05 and 2.20) respectively as seen in table 3. The fruits and vegetable are better stored as seeds especially when seed are dried. This is reflected by the responds from our respondents. Dried seeds pepper, fluted pumpkin, okro and cucumber had higher mean value of $2.95,3.00$ and 3.25 respectively.

\section{The Extent of Effectiveness of Indigenous Method of Food Crop Preservation.}

\section{Tubers}

Evidence has shown that storing yam tubers in barn is a conventional way of preserving its shelf life to the next cropping season, particularly seed yam as seen in table $4 \mathrm{a}$. But they are not satisfactory, because the tubers are "actively living tissues with a high water content" and are susceptible to rapid deterioration due to sprouting and respiration. The National Stored Product Research Institute (NSPRI) believes that yam tubers can be stored up to 9 months if stored somewhere at $15^{\circ} \mathrm{C}$. (Onuegbu, 2002). However, processing the tubers into flour and yam chips 
(for consumption) apparently preserves its shelf life better on account hence these methods recorded. The highest mean values of 3.85 and 3.80 respectively. This is comparable to cassava stored in processed form as garri, flour and dried tapioca which also recorded high mean values of 3.50, 3.40 and 3.75 respectively (Table 1).

A similar observation was noted in cocoyam. The shelf life of cocoyam is preserved when processed into chips and flour (3.50 and 3.60 respectively) as shown in Table 4. Cassava roots are highly susceptible to deterioration and have no dormancy period. This has for a long time made the storage almost impossible, hence it is better stored when processed into garri or tapioca. Cocoyam is not highly susceptible to deterioration as compared to cassava. There is no well defined method of storage, however wood ash have been employed in reducing rot. In a processed form, the content of tubers which predisposes them to pathogenic infection and internal enzyme reactions is reduced consequently, infection is greatly reduced; hence the shelf life is preserved. On the contrary, when the tubers are stored unprocessed the moisture content is high and intact at ambient temperature. Pathogens thrive very well in moist environment which leads to deterioration, hence shelf life is shortened.

\section{Cereals and Legumes}

The principle of dehydration is also applicable in the preservation of shelf-life of grains. The shelf life of grains is preserved when dried or processed into flour as shown in table 5. The addition of dried pepper to stored grain is an added advantage to guide against insect infestation. All of these measures guarantee a long shelf-life to a high extent. Evidence has shown that dehusked maize cobs stored in the method described earlier are more susceptible to pests than unhusked ones. These methods can keep maize for 6 to 12 months. One of the disadvantages being that some of the kernels lose viability as the number of months increases (Onuegbu, 2002).

\section{Fruits and Vegetables}

Preserving the shelf-life of leafy vegetable is almost impossible, that explains why rural farmers harvest them in piece meal either for sale or consumption. Personal communications with many of these rural farmers claim that the leafy vegetables stored by keeping in the dews at night or tying in a fresh plantain leave could store up to 2-4 days. If the vegetables are needed to stay longer, they are normally processed into smaller particles by washing, squeezing and drying in the sun or over fire or oven at low temperature. It is clear that not much has been done on the storage of leafy vegetables in Nigeria. However, preserving the shelf life of bitter-leaf is achievable when it is crushed and dehydrated. Hence, it recorded the highest mean value 3.10 (Table 6) the shelf life of other vegetable crops life pepper and okro among others can be preserved to a high extent when sun dried or smoked as shown in Table 6. This confirms the earlier findings of Nnadi et al., (2013) who reported that in Anambra State Nigeria, 80\% of rural farmers used sun-drying for food preservation. Tying dried seeds of okro over fire place guarantees better storage because the smoke from the fire tries to keep weevils and other pests away as well as reduce the water content of seed to the bearest minimum, hence dried okro seed hung over fire place recorded the highest mean value of (3.80). This agrees with the finding of Onuegbu (2002) and Chirimuuta and Mapolisa (2011). Storing fruits in pot-in-pot-evaporator 
cooling system is a more refined method of storage, however, the method is uncommon to the locals in Etche, hence it recorded the least mean value of 2.25 .

\section{Strategies of Improved Method Food Crop Storage/Preservation}

\section{Tubers}

The NSPRI believes that yam tubers can be stored for up to 9 months if stored at $15^{\circ} \mathrm{C}$ or treated with gamma rays within 4 weeks of harvesting. Dipping fresh tubers into benomyl, dithane-M45 and captan have been known to reduce rot. Food and Agriculture Organization (FAO) reports (1991) held that the tubers could last for up to 3 days if the plants stems are cut leaving the tubers unharvested till the 14th days after cutting. F.O.A report (1984) also explained that cassava tubers could last for 4-6days after coating them with paste made from earth or mud.

However, investigations at Nigerian Stored Product Institute (NSPRI) points to practical tips for storing cassava tubers for up to 10 weeks. Freshly harvested roots with a bit of stump can be stored in moist saw-dust in baskets or boxes. They can also be placed between layers of raffia or palm leaves in a trench covered with soil and shade made over the trench. The later method of storing cassava tubers is beginning to gain wide acceptability by poor resource-based farmers (Onuegbu 2002).

\section{Cereal and Legume}

Research stations in Nigeria have developed systems of storing cereals to prevent huge losses accruing from the use of traditional storage systems. Some of these methods include the improved ventilated cribs, modern silo and inert atmosphere storage silo.

\section{Fruits and Vegetable}

Nigerian Stored Product Research Institute (NSPRI) has devised some methods of storing some perishables notable among these methods is Evaporator Coolant Systems (ECS). Two types of this system have been devised, namely, pot-in-pot evaporator coolant system and met-in-wall evaporator coolant system.

The advantages of evaporator coolant system are as follows

i. $\quad$ No electricity is required

ii. It can be used in rural areas

iii. It prolongs the shelf-life of fruits

iv. It can be constructed from locally available material

\section{CONCLUSION AND RECOMMENDATIONS}

The indigenous methods of food crop storage and preservation are age-long, time tested and have been used by locals in Etche to preserve their produce after harvest. However, the methods are not effective to preserve food for a long time as found from this study. It is therefore recommended that improved methods of food crop storage and preservation be adopted by the locals. This is achievable by the following measures. 
1. Government should adopt policies that will encourage rural farmers assess modern facilities for food crop storage/preservation.

2. Food processing facilities such as machines should be provided for rural farmers either by Government of Non-Government organizations (NGOs) or well meaning individuals.

3. Training and retaining of rural farmers on the use of preservatives such as fungicides and pesticides should be encouraged.

\section{REFERENCES}

Agea, J.G., Lugangwa, E., Obua, J. \& Kambugu, R.K., (2008). Role of indigenous knowledge [51 in enhancing household food security: A case study of Mukungwe, Masaka district, Central Uganda. indilinga - African Journal of Indigenous Knowledge Systems, 7(1). 6571.

Awojobi, B.F, (2004). Indigenous knowledge in potato utilization, processing and preservation. In Olakesusi, F. (Eds). Proceedings of Post Harvest Seminar: Nigerian Stored Products Research Institute Ilorin, 1-127.

Black, R.E., Allen, L.H, Bhutta, Z.A., Caulfield, L.E., de Onis, M., Ezzati, M., Mathers, C. (2008) \& Rivera, J, Maternal and child under nutrition: global and regional exposures and health consequences. The Lancet. 371(960). 243-260.

Chirimuuta, C \& Mapolisa, T, (2011). Centering the peripherised systems: Zimbabwean indigenous knowledge systems for food security. Zimbabwe international Journal of Open \& Distance Learning. 1(2). .52-56.

Ezeike, G.O.I, (1995). Successful introduction of improved yam storage methods for Nigerian farmers. in: FAO (ed.) Proceeding of the Workshop on the African Experience on Postharvest Technology Development, Accra (Ghana), 4-8 July.

FAO, (2011). Global food losses and food waste - extent, causes and prevention. Food and Agriculture Organization of the United States, Rome.

Goqestani, N, (2004). Indigenous knowledge for development opportunities and challenges. In: Twarog, S. and Kapoor, $\mathrm{P}$, (Eds), Protecting and promoting traditional knowledge systems, national experiences and international dimensions. United Nations Publication, Symbol No. UNCTAD/DITC/TED/1 0.

Gustavsson, J, Cederberg, C., Sonesson, U,, Otterdijk, R. \& Meybeck, A, (2011). Global Food Losses and Food Wastes: Extent, Causes and Prevention. [Online] Available at: http://www.fao.org/fileadmin/user upload/ags/publications/GFL web. pdf.

(Accessed Nov. 19th, 2015). 
Jayas, D.S \& White, N.D.G, (2003). Storage and drying of grain in Canada: low cost approaches. Food Control. 14. 255-261.

Kamwendo, G. \& Kamwendo, J, (2014). Indigenous Knowledge-Systems and Food Security: Some Examples from Malawi. Journal of Human Ecology. 48(1). 97-101.

Katz, H.S. \& Weaver W.W, (2003). Encyclopedia of food culture Volume 1.

Melchias, G, (2001). Biodiversity Conservation Enfield Science Publishers, Inc.,

Modi, A.T. (2004). Short-term preservation of maize landrace seed and taro propagules using indigenous storage methods, South African Journal of Botany, 70. 16-28.

Olakojo, S.A. \& Akinlosotu, T.A, (2004). Comparative study of storage methods of maize grains in South Western Nigeria. African Journal of Biotechnology. 7. 362-365. Proceedings of Workshop on Processing, Marketing and Utilization of Root and Tuber Crops in Africa, international institute for Tropical Agriculture Ibadan. 91-102. 1992.

Onuegbu B. A. (2002). In Fundamentals of Crop Protection. Agro Service Consult and Extension Unit, Faculty of Agriculture, Rivers State University of Science and Technology, Port Harcourt, Nigeria.

Sanni, L.O., Adebowale, A.A., Awoyale, W \& Fetuga, G.O. (2008). Quality of garri (roasted cassava mash) in Lagos State. Nigeria. Nigerian Food Journal. 26. 125-130.

Thamaga-Chitja, J.M., Hendriks, S.L., Ortmann, G.F. \& Green, M, (2004). Impact of maize storage on rural household food security in northern KwaZulu- Natal. Journal of Family Ecology and Consumer Science. 32. 8-15.

Woolfe, I. (1992). Sweet Potato: A versatile and Nutritious Food for all. In: Scott, G., Ferguson, P.1. and Herara, J.E. (Eds). Product Development for Root and Tubers Crops, Vol. III. Proceedings of Workshop on Processing, Marketing and Utilization of Root and Tuber Crops in Africa, International Institute for Tropical Agriculture Ibadan, 91-1-2.

Nnadi, F.N. Chikaine, J. \& Ezudike, K.E (2013). Assessment of Indigenous Knowledge Practices for Sustainable Agriculture and Food Security in Idemilu South Local Government Area of Anambra State, Nigeria. Journal of Resources Development and Management 1, 1421.

Yakubu, D.A. (2000). A Study of various Local Methods of Potati Storage, Kaduna, Nigeria. Kaduna Polytechnic. National Diploma Project (Unpublished). 